\title{
STUDENT'S IDEAS ABOUT THE PREREQUISITES AND MEASURES TO COMBAT CORRUPTIONS
}

\author{
Olga Deyneka \\ Saint Petersburg State University (Russia)
}

\begin{abstract}
In the context of "creeping" everyday corruption, it is extremely important to monitor attitudes towards corruption, especially among young people. The objective of the study was to identify the problems in attitude to corruption in Russia among students. The total sample included 181 students: 106 university students from St. Petersburg, Moscow and Chelyabinsk, and 81 students from St. Petersburg colleges. The study showed that the students associated responsibility for the level of corruption primarily with the institutions of power, accusing legislative branch and sharing the view of the weak interest of the government in eliminating corruption. According to students, combating corruption is also difficult due to the fact that corruption is not condemned in society. Correlation analysis of the data showed that those students who know the articles of the Criminal code of the Russian Federation related to corruption, higher assess the effectiveness of Russian legislation in combating corruption. The result confirms the importance of improving the legal culture of students, as in the protest movement corruption is often the cause of destructive protests. As the most effective measures to combat corruption, students identify anti-corruption civic education and interaction with international organizations, and the least effective measure is considered fines. The results can be used in the development of educational programs.
\end{abstract}

Keywords: Attitudes, corruption, students, countermeasures, prerequisites.

\section{Introduction}

In everyday consciousness, corruption is most often reflected as a bribe. However, corruption is a broader concept. Corruption refers to deviations from a binding legal norm, arbitrariness in the exercise of authority and the illegal use of public resources. Indeed, no one is surprised at the offers to buy any product or service, provided that part or full payment passes without going through the cashier's office (for example, this happens with theater tickets, technical inspections of cars).

Corruption acts include bribery of officials and public and political figures, bribery for legal and illegal representation of benefits and advantages, protectionism. Against the background of the promotion of enterprise among public servants while reducing the control of their activities in the early 1990s (and in the absence of legislative reinforcement for many transactions between administrations and businesses) moral deformations have intensified (Nestik, 2002), corruption has become a way of life and a certain social norm (Simoniya, 2000).

Recently, Russia has been actively, but to a certain degree, working to combat corruption. It should be noted public exposures of corrupt officials from the authorities. Prevention of corruption is carried out through the introduction of special disciplines and online courses in educational programs in universities. In this regard, it is important to monitor attitudes towards corruption, especially among young people.

\section{Background}

The consequences of acts of corruption can be economic, political and psychological. As the socio-psychological mechanisms of corruption are compelled conformal behavior (Nestik, 2002), "corporate" morality (Deyneka, 2013), lack of social capital (Coleman, 1988; Corruption and..., 2007), Eastern tradition's archetypes (Boronoev \& Smirnov, 2000; Reshetnikov, 2008; Kitova, Zhuravlev, Sosnin, Yurevich, 2017). Psycho-political prerequisites of corruption are paternalism, hierarchy and reliance on informal relations with the authorities, as well as periods of modernization (Huntington, 1996) in the absence of a clear concept and ignoring the socio-cultural traditions of society, low legal culture of citizens, combined with religious and national heterogeneity of the population. 
Despite their relevance, empirical work on the economics and psychology of corruption has long been presented poorly (Braun M., Di Tella R., 2004). Currently, the interest of scientists to the problem of corruption has intensified.

To substantiate the relevance of the new research on attitudes towards corruption, we analyzed the dynamics of the reflection of corruption as an acute problem of society among student youth in the period from 2010 to 2018 using the Citizen Questionnaire. In the block of problems of modern society, young people consistently put the problem of corruption in the first place, along with a large stratification of society. Less important were such issues as raising the retirement age, unemployment and migration. Table 1 shows descriptive statistics of student research data in different years.

Table 1. Assessment of the severity of the problem of corruption in different years among students.

\begin{tabular}{|c|c|c|c|c|c|}
\hline \multicolumn{6}{|c|}{ The degree of students' consensus that corruption is the main problem of Russian society } \\
\hline 2010 & 2013 & 2014 & 2015 & 2016 & 2017 \\
$(\mathrm{n}=94)$ & $(\mathrm{n}=208)$ & $(\mathrm{n}=227)$ & $(\mathrm{n}=227)$ & $(\mathrm{n}=231)$ & $(\mathrm{n}=211)$ \\
\hline $\mathrm{M}=6,56 ;$ & $\mathrm{M}=5,69 ;$ & $\mathrm{M}=5,19 ;$ & $\mathrm{M}=5.64 ;$ & $\mathrm{M}=5.65 ;$ & $\mathrm{M}=6,05 ;$ \\
$\sigma=0,07$ & $\sigma=1,36$ & $\sigma=1,33$ & $\sigma=1,69$ & $\sigma=1,46$ & $\sigma=1,16$ \\
\hline
\end{tabular}

Over the past years, the problem of corruption in the minds of young people has retained the status of the most acute problem and, as can be seen from table 1, does not lose relevance.

The objective of this study was to identify problems in attitude to corruption in Russia among students, to study students' ideas about the prerequisites and measures to counter corruption.

\section{Method}

The method of the research was the short version of the questionnaire "Attitudes towards corruption", consisting of 18 claims with a 7-point scale responses. The questionnaire includes the following blocks: attitudes to anti-corruption measures; pretensions to power, critical attitude toward authority; assessment of the current state of corruption in government institutions in the country.

Two groups of students took part in this study. The total sample included 181 students: 106 university students from St. Petersburg, Moscow and Chelyabinsk (the sample consisted of $75 \%$ female and $25 \%$ male students; the average age was 22.9), and 81 students from St. Petersburg colleges ( $78 \%$ female and $22 \%$ male students; the average age was 18.0 ).

\section{Results}

The results showed that the students associated responsibility for the level of corruption primarily with the institutions of power, accusing legislative branch and sharing the view of the weak interest of the government in eliminating corruption $(\mathrm{M}=5.26, \mathrm{SD}=1.74)$. According to students, combating corruption is also difficult due to the fact that corruption is not condemned in society $(\mathrm{M}=4.42, \mathrm{SD}=1.71)$. At the same time, respondents do not consider the use of bribes as the norm of modern business $(\mathrm{M}=2.98, \mathrm{SD}=1.73)$.

As the most effective measures to combat corruption, students identify anti-corruption civic education and interaction with international organizations, and the least effective measure is considered fines (table 2).

Table 2. Evaluating the effectiveness of anti-corruption measures.

\begin{tabular}{|c|c|c|c|}
\hline $\begin{array}{l}\text { Countermeasures and Prevention of } \\
\text { Corruption }\end{array}$ & Rank & M & SD \\
\hline $\begin{array}{l}\text { Anti-corruption civic upbringing and } \\
\text { education }\end{array}$ & I & 5.74 & 1.38 \\
\hline $\begin{array}{l}\text { Interaction with international } \\
\text { organizations }\end{array}$ & II & 5.01 & 1.53 \\
\hline Citizens' Anti-Corruption Education & III & 4.43 & 1.72 \\
\hline $\begin{array}{l}\text { Public condemnation of corruption in the } \\
\text { media and the Internet }\end{array}$ & IV & 4.02 & 1.90 \\
\hline $\begin{array}{l}\text { Ethical standards and commissions for } \\
\text { civil servants }\end{array}$ & $\mathrm{V}$ & 3.51 & 1.55 \\
\hline Fines & VI & 3.45 & 1.80 \\
\hline
\end{tabular}


"Anti-corruption education" is considered as one of the directions of the general prevention of crimes and represents the education of human values (Nikolaev, 2011). The result obtained is an indirect evidence of the approval among students of the introduction of special programs in universities and colleges. Such programs could increase the "anti-corruption resistance" (Vanovskaya,2013).

Estimates of the causes (preconditions) of corruption in modern Russian society are given in Table 3 in descending order of their importance.

Table 3. Estimates of the preconditions of corruption.

\begin{tabular}{|c|c|c|c|}
\hline $\begin{array}{c}\text { Countermeasures and Prevention of } \\
\text { Corruption } \\
\end{array}$ & Rank & M & SD \\
\hline $\begin{array}{l}\text { Low effectiveness of anti-corruption } \\
\text { legislation }\end{array}$ & I & 5.91 & 1.38 \\
\hline Low salaries of employees & II & 4.84 & 1.73 \\
\hline $\begin{array}{l}\text { No Condemnation of Corruption in } \\
\text { Society }\end{array}$ & III & 4.42 & 1.71 \\
\hline Gaps in the laws & IV & 3.41 & 1.71 \\
\hline
\end{tabular}

It should be noted that the assessment of the effectiveness of anti-corruption laws in Russia was closely related to economic optimism (I think that the economic situation in Russia will improve in the next 5 years) among university students $(\mathrm{r}=0.49)$ and even more among college students $(\mathrm{r}=0.56)$.

Four factors were identified as a result of factor analysis of the questionnaire data. As can be seen from table 3, the data of the questionnaire formed four well-interpretable factors: the factor of the effectiveness of the fight against corruption; the anti-corruption measures factor; the corruption prerequisites factor; the factor of social norms due to corruption.

Table 3. The factor structure of the questionnaire "Attitudes towards corruption" data.

\begin{tabular}{|c|c|}
\hline Statements & $\begin{array}{l}\text { Factor } \\
\text { loading }\end{array}$ \\
\hline \multicolumn{2}{|l|}{ The Factor of the Effectiveness of the Fight against Corruption (9.6) } \\
\hline Existing Russian legislation is effective in the fight against corruption. & -0.750 \\
\hline I think that the economic situation in Russia will improve in the next 5 years. & -0.731 \\
\hline I am convinced that our government is not interested in eliminating corruption. & 0.718 \\
\hline $\begin{array}{l}\text { I believe in the principle of good faith in relation to competitions and tenders in the Russian } \\
\text { Federation. }\end{array}$ & -0.486 \\
\hline I am convinced that corruption undermines the economy and national security & 0.415 \\
\hline \multicolumn{2}{|l|}{ The Anti-Corruption Measures Factor (7.2) } \\
\hline $\begin{array}{l}\text { Public condemnation of corruption in the media and the Internet is the most effective } \\
\text { measure to eliminate corruption. }\end{array}$ & 0.788 \\
\hline Citizens' anti-corruption education is the best measure to fight corruption. & 0.722 \\
\hline I am convinced that anti-corruption civic education and upbringing are necessary. & 0.615 \\
\hline \multicolumn{2}{|l|}{ The Corruption Prerequisites Factor (6.4) } \\
\hline $\begin{array}{l}\text { The lure of corruption is especially great against the background of low wages of } \\
\text { employees. }\end{array}$ & 0.585 \\
\hline $\begin{array}{l}\text { The most dangerous type of corruption for modern Russia is corruption in law } \\
\text { enforcement. }\end{array}$ & 0.570 \\
\hline Gaps and vagueness of interpretations in laws are the main cause of corruption. & 0.500 \\
\hline I know about articles of the Criminal Code related to corruption. & -0.495 \\
\hline $\begin{array}{l}\text { Active interaction with international organizations in the fight against corruption can have } \\
\text { positive consequences for Russia. }\end{array}$ & 0.430 \\
\hline \multicolumn{2}{|l|}{ The Factor of Social Norms due to Corruption (5.2) } \\
\hline I consider the use of bribes the norm of modern business. & 0.725 \\
\hline I am convinced that corruption undermines the economy and national security. & -0.506 \\
\hline Anti-corruption is difficult because it is not condemned in society. & 0.448 \\
\hline
\end{tabular}

Correlation analysis of the data showed that those students who know the articles of the Criminal Code of the Russian Federation related to corruption, higher assess the effectiveness of Russian legislation in combating corruption $(\mathrm{r}=0.28, \mathrm{p}<0.01)$. The result confirms the importance of improving the legal culture of students, as in the protest movement corruption is often the cause of destructive protests. 
The role of interaction with international organizations in the fight against corruption was considered significant by those students who advocate anti-corruption education $(\mathrm{r}=0.30, \mathrm{p}<0.01)$, and those who are more concerned about corruption in law enforcement $(r=0.29, p<0.01)$. The result obtained is not unfounded. Corruption in law enforcement agencies, designed to satisfy the motive of citizens' safety, is still present. As shown by our comparative studies of attitudes towards the corruption of citizens of Russia and Italy (Deyneka, 2015), among Russians there were more of those who had claims to law enforcement agencies than among Italians.

\section{Conclusions}

The triad of representation of the prerequisites of corruption in the minds of students includes problems related to power and laws, economics, and public opinion.

The students identify anti-corruption civic education, interaction with international organizations, and citizens' anti-corruption education as the most effective anti-corruption measures. They consider fines to be the least effective measure.

Thus, it can be said that in the public opinion of young people there is a willingness to educate as part of special educational programs to improve anti-corruption sustainability and legal culture.

\section{References}

Boronoev A.O., Smirnov P.I. (2000). Russian mentality and reform. (Ed. V. Bolshakov). Society and Politics: Current research, search concepts. St. Petersburg: St. Petersburg State University. 274 -303. (in Russia).

Braun M., Di Tella R. Inflation, Inflation Variability, and Corruption. Economics and Politics. 2004. 16(1), 77-100.

Coleman, J. S. (1988). Social capital in the creation of human capital. American Journal of Sociology. 94, 95-120.

Deyneka O.S. (2013). Political psychology and crime prevention in economics and business. Saarbruecken: Palmarium Academic Publishing (in Russia).

Deyneka O. (2015). Attitude toward corruption: two comparative studies. InPACT 2015. Ljbljna, Slovenia. 2-4 May. Proceedings. Ed. by Clara Pracana. Lisbon: W.I.A.R.S. 156 -159. http://inpactpsychologyconference.org/wp-content/uploads/2014/04/InPACT-2015_Proceedings.pdf

Corruption and the Secret of Law: A Legal Anthropological Perspective. (2007). Ed. Nuijten M, Anders G. London: Routledge.

Huntington S. F. (1996). Clash of Civilizations and the Remarking of Word Order. New-York: Simon \& Schuster.

Kitova D.A., Zhuravlev A.L., Sosnin V.A., Yurevich A.V. (2017). Corruption as an object of socio-psychological research: status and prospects. Institute of Psychology of the Russian Academy of Sciences. Social and economic psychology. V. 2. № 3 (7). 6-38. http://soc-econompsychology.ru/engine/documents/document370.pdf

Nestik T.A. (2002). Corruption and Culture. The economic theory of crime and punishment. 4 (2). http://corruption.rsuh.ru/magazine/4-2/n4-05.html

Nikolaev S.M. The concept and essence of anti-corruption education. Historical, philosophical, political and legal sciences, cultural studies and art history. Questions of theory and practice. Tambov: Diploma, 2011. 7 (2), 159-162. http://www.gramota.net/materials/3/2011/7-2/42.html

Reshetnikov M.M. (2008). Psychology of Corruption: utopia and dystopia. St.-Petersburg: East European Institute of Psychoanalysis.

Simonia N.A. On corruption and the state. Person and the world. Moscow. Russian Academy of Natural Sciences. Institute of Federalism and Civil Society. 2000. 7.7-15.

Vanovskaya O.V. (2013). Psychology of corrupt behavior of civil servants. St. Petersburg: LLC "Book House". (in Russia). 